\title{
Determinants of Compliance to Good Agricultural Practices among Cocoa Farmers in Ondo State, Nigeria
}

\author{
Nathaniel Siji Olutegbe* and Abdullahi Oluwadamilola Sanni \\ Department of Agricultural Extension and Rural Development, University of Ibadan, Ibadan, Nigeria \\ *Corresponding author: siji004u@yahoo.com
}

\begin{abstract}
Cocoa is one of Nigeria's most important agricultural commodities due to its status as a source of foreign exchange earnings. However, low quality and hence low patronage of cocoa beans of Nigeria origin has reduced this fortune in recent years due mainly to non-adherence to Good Agricultural Practices (GAP) among farmers. The study therefore identified the determinants of compliance to GAP among cocoa farmers in Ondo State, Nigeria. A three-stage sampling procedure was used to select 20\% (150) of cocoa farmers across randomly sampled cocoa-producing communities in Ondo State. Information was sourced using a well-structured, validated questionnaire. Data were analyzed using frequency counts, mean and Ordinary Least Square (OLS). Majority of farmers had good knowledge of GAP. However, farmers were mostly faced with constraints such as high cost of agrochemicals and labor scarcity. Farmers rated economic benefits of GAP as high; while health and environmental benefits were rated low; with high acceptability of cocoa; utilization of soil organic matter and prevention of respiratory malfunctioning identified as top economic, environmental and health benefits, respectively. Although the general compliance was high across different GAP, practices to which farmers were least compliant were however of relatively high economic, health and environmental implications. Knowledge, perceived health and perceived economic benefits of GAP were important determinants of compliance. The extension unit of the Ondo State Ministry of Agriculture should prioritize sensitization and education of farmers on the economic, health and environmental benefits of GAP of cocoa in order to ensure profitability and sustainability of production.
\end{abstract}

Keywords: cocoa; economic; environment; Good Agricultural Practices; health

Cite this as: Olutegbe, N. S., \& Sanni, A. O. (2021). Determinants of Compliance to Good Agricultural Practices among Cocoa Farmers in Ondo State, Nigeria. Caraka Tani: Journal of Sustainable Agriculture, 36(1), 123-134. doi: http://dx.doi.org/10.20961/carakatani.v36i1.44894

\section{INTRODUCTION}

Before the discovery of crude oil, agricultural crops like cocoa were one of the most important sources of revenue and it played prominent roles in the growth, development and stability of the nation's economy (Afolayan and Ajibade, 2012). Since after its introduction, West Africa has been the center of production; accounting for twothirds of the world's cocoa (Afolayan, 2017). Cocoa production in Nigeria gained rapid prominence to the extent that Nigeria was the second largest producer in the world by 1965 and continued to maintain the status until the days of increasing oil exploration. During this time, cocoa was the major leading cash and export crop in the southern part of Nigeria, with Ondo State being the most prominent (Owoeye and Sekumade, 2016; Afolayan, 2017). Other states within the country, ranked in order of prominence, include Cross River, Osun, Ekiti, Oyo, Edo, Ogun, Delta, Abia and Akwa-Ibom (National

\footnotetext{
* Received for publication October 16, 2020

Accepted after corrections December 29, 2020
} 
Bureau of Statistic - Nigeria, 2013b). Also, cocoa, during this period, ranked the first Nigerian exchange commodity such that the revenue gotten from the export was used to finance free education in the south-western region, building monuments such as the Cocoa House Building, Obafemi Awolowo University and Obafemi Awolowo Stadium (formerly known as Liberty Stadium) in Ibadan. Production increased gradually to 308,000 metric tons in 1970/71 (Afolayan, 2017).

However, with the emergence of other sources of revenue, particularly crude oil, cocoa production witnessed a decline. This was also blamed by Awe (2013) on military intervention in Nigeria politics in the 80s. By 1999, the production level had declined to 225,000 metric tons (Afolayan, 2017). By 2012, Cadoni (2013) had also presented Nigeria among the lowest in cocoa yield alongside Ghana and Cameroon, while Côte d'Ivoire and Indonesia were ranked first and second, respectively. Currently, Nigeria ranks the third largest producer of cocoa and sixth globally. However, despite the near absolute paradigm shift by the government from agriculture to crude oil and discouraging production statistics, cocoa still remains the third source of foreign exchange earning in Nigeria.

While a number of variables have been identified as responsible for the declining production metrics, specifically and of direct bearing is poor agricultural practices often adopted in an attempt to get rid of pests and diseases which are the most common constraints to cocoa production. In addition, problems such as low fertility, climate change, global price fluctuation, insufficient processing firms and inadequate access to production inputs such as fertilizers are posing great challenges towards sustainable cocoa production in Nigeria (Afolayan, 2017). It is important to realize that loss of nutrients occurs every year, having cumulative effect on soil nutrient status. Indiscriminate cutting down of forest, which seems to be the quest efforts at augmenting production and filling the deficit due to aging of cocoa farms has also been on the increase, with devastating implications for environmental health and sustainability of cocoa production. For example, Morgan-Davies et al. (2017) and Jumiyati et al. (2018) in separate studies concurred that agriculture development that is directed to boost production for self-sufficiency most often results in the occurrence of environmental disasters and over-exploitation of natural resources, which in time would result in the scarcity of essential environmental resources.

In another study, Arsyad et al. (2020) also averred that the agricultural practice (such as monoculture) is vulnerable to various environmental constraints and this has negative implications for farmers productivity and income. In contrast, the demand for cocoa, which is largely determined by external factors, has been projected to be on the rise. For example, Beg et al. (2017) had predicted a $35 \%$ rise in the demand for cocoa by 2020 . In the face of this increasing demand as projected, the need to command good price in the global market therefore becomes very imperative. Also, Paschall and Seville (2012) assert that about $60 \%$ of the world's cocoa is used in chocolate products while the remaining $40 \%$ are used for a range of bakery, confectionery and drink products. The continued dependence of Nigeria on other countries for such cocoa products as chocolate and other confectioneries due to non-presence of local industries however, forces cocoa actors in Nigeria to depend on the market force as largely determined by players outside the shore of the country.

The government of Nigeria had in the past made several efforts at improving production, adding value to meet quality standard and ensuring the sustainability of cocoa enterprise. One of such efforts was the establishment of the National Cocoa Development Committee (NCDC). According to Ibiremo et al. (2011), the NCDC was setup to provide recommended agrochemicals for farmers at subsidized rate to help combat pest and diseases of cocoa, rehabilitate and regenerate old and unproductive cocoa and sensitize and train farmers on new technologies in cocoa production. Another effort was the establishment of the Cocoa Commodity Board (which has been defunct) to help regulate prices and set good standard for cocoa production. The NCDC was also established with an objective of cocoa rehabilitation and regeneration. The Cocoa Research Institute of Nigeria (CRIN), which has been in operation for decades and have in line with their mandates generated cocoa technologies and improved varieties, while ensuring that such are transferred across to the farmers and other stakeholders.

The CRIN have also released various research recommendations aimed at improving cocoa production generally. Trainings and extension 
activities have been conducted with farmers on Good Agricultural Practices (GAP) of cocoa. Cocoa production and information on GAP are also the fulcrum of the agricultural extension activities of the Ondo State Agricultural Development Program. GAP, according to Banzon et al. (2013), refer to approaches for sustainability agriculture, safety and quality food by improving supply chain control, improving natural resource utilization, workers health and working conditions, consumers and farmers families' health and creating new market opportunities for farmers. However, these efforts have not been able to reinstate Nigeria back to its previous rank of being the $2^{\text {nd }}$ largest producer of cocoa in the world as the country currently ranks $4^{\text {th }}$ (Okojie, 2020).

Rejection rate of cocoa beans by international agents, an indication of non-adherence to GAP, has also been on the rise (Gumm, 2010; Ogundele, 2018). Unfortunately, previous researches have only favored agronomic phase of GAP for cocoa, with less attention on the post-agronomic phase. Hence, Zhen and Routray (2003) posits that meeting global market demand requires the sustainable development paradigm of increasing awareness, concern and product quality. Therefore, the dearth of information on compliance to GAP across the entire production chain of cocoa with a view to ensuring improved quality and hence profitability among cocoa small-holders necessitates this study. The need to investigate the determinants of compliance to the GAP among cocoa among farmers, therefore, becomes imperative. The study assessed farmers' knowledge of GAP of cocoa ascertained perceived benefits of GAP of cocoa among farmers, identified constraints inhibiting compliance to GAP and evaluated how compliant cocoa farmers are to GAP.

\section{MATERIALS AND METHOD}

The study was carried out in Ondo State, South-western part of Nigeria between August and December, 2019. The State borders Ekiti State to the north, Kogi State to the northeast, Edo State to the east, Delta State to the southeast, Ogun State to the southwest and Osun State to the northwest. The state has a total land area of 14,606 $\mathrm{km}^{2}(5,639 \mathrm{sq} \mathrm{mi})$. The ethnic composition of Ondo State is largely from the Yoruba Sub-groups of the Akoko, Akure, Ikale, Ilaje, Ondo and Owo people. Agriculture is the mainstay of the economy in the state and one of the chief products. Ondo State ranks highest on the list of states designated as cocoa producing, contributing $24 \%$ of the country's overall output (National Bureau of Statistic - Nigeria, 2013a). The state produced a total of 91.99 metric tons, equivalent to $25 \%$ of the Nigeria's overall production for the year in 2012 (National Bureau of Statistic - Nigeria, 2013a).

A number of studies have also alluded to Ondo State being the most prominent for cocoa production in Nigeria (Adegeye, 1996; Aikpokpodion, 2010; Ajayi et al., 2010; Afolayan and Ajibade, 2012; Afolayan, 2020). Other commonly cultivated crops are yam, cassava, maize, vegetables and fruits, cotton and tobacco, while other economic activities include trade, public service employment, service sector, among others. The population of the study comprised all cocoa farmers in Ondo State. A multistage sampling procedure was used to select respondents for the study. The first stage involved the selection of three Local Government Areas (LGAs) through a simple random selection procedure. These are Odigbo, Ondo West and Owo. Second stage also involves a random selection of twenty percent $(20 \%)$ of the communities in each of the wards (each LGA has an average of ten wards). The third stage involves proportionate sampling of farmers from the list obtained from the Cocoa Farmers Association. This gives a total of 150 cocoa farmers, representing $20 \%$ of the population in each of the selected wards. Table 1 shows the details of the sampling procedure.

Structured questionnaire, administered in the form of interview, was used to gather information from respondents, while direct observation was employed as a complementary approach to validate compliance to GAP among farmers. Apart from the socioeconomic characteristics of farmers, other key variables as implied in the research questions were measured. Knowledge of GAP was measured by drawing questions on GAP to which responses were obtained as 'True', 'False' and 'I don't know', where either 'False' or 'True' was the correct answer to each question, while 'I don't know' assumed a constant 'incorrect' status. The 'I don't know' option was included to serve as a control option to avoid forced response to either 'false' or 'true' and assumed a score of 0 while an incorrect response 
was scored 1. A knowledge score was obtained and the mean was computed and used as a benchmark for low and high knowledge dichotomies. Knowledge level as it relates to GAP was considered based on prevailing farming operations and FAO international code of practice for cocoa. Constraint to GAP was measured as farmers were presented with a list of constraints faced to adhering to GAP. It was measured using a three-point scale of 'severe', 'mild' and 'not a constraint' with scores 2, 1 and 0 assigned, respectively. Weighted mean scores were calculated and used to rank the constraints faced by farmers in adhering to GAP in order of importance. Scores were also obtained and used to run the hypothesis.

Table 1. Showing sample for the study

\begin{tabular}{|c|c|c|c|c|}
\hline $\begin{array}{l}\text { Local government area } \\
\text { (prominence of cocoa) }\end{array}$ & $\begin{array}{c}\text { Number of } \\
\text { wards }\end{array}$ & $\begin{array}{c}20 \% \text { of } 10 \\
\text { wards }\end{array}$ & $\begin{array}{l}\text { 1 Community } \\
\text { in each ward }\end{array}$ & $\begin{array}{l}\text { Number }(20 \%) \text { of farmers } \\
\text { selected in each ward }\end{array}$ \\
\hline \multirow[t]{2}{*}{ Owo } & 11 & 2 & Ijebu-Owo & 30 \\
\hline & & & Iyere & 20 \\
\hline \multirow[t]{2}{*}{ Odigbo } & 10 & 2 & Ajue & 27 \\
\hline & & & Oro & 23 \\
\hline \multirow[t]{2}{*}{ Ondo West } & 12 & 2 & Laje & 21 \\
\hline & & & Ondo town & 29 \\
\hline Total & & & & 150 \\
\hline
\end{tabular}

In operationalizing perceived benefits of GAP, farmers were asked of perceived benefits of GAP along each benefit domain of economic, environmental and health. It was measured on a 3-point scale of 'high', 'moderate' and 'low', with scores of 3, 2 and 1 assigned, respectively. Weighted mean was obtained for different items along each domain and used to rank the benefit items in order of importance. Mean of mean was obtained for each domain for the purpose of comparing across the three domains the study assessed. An overall benefit score was obtained for each domain and used in the test of hypothesis. The dependent variable of the study is compliance to GAP by cocoa farmers. This was measured on a 2-point scale of 'compliant' and 'non-compliant', with score of 1 assigned to every item to which cocoa farmers complied and 0 to non-compliant. In achieving this, researcher made use of any of indirect questions, direct questions, direct observations or any combination of these across different recommended GAP of cocoa. The choice of approach for ascertaining compliance to each item was determined by the peculiar nature of such item. A score of compliance was also obtained as a function of the number of GAP to which each cocoa farmer adhered.

Descriptive statistics such as mean, frequencies percentage and OLS regression analysis were used to analyze the data collected. The equation is stated as:

$$
\mathrm{Y}=\mathrm{f}\left(\mathrm{X}_{1}, \mathrm{X}_{2}, \mathrm{X}_{3}, \mathrm{X}_{4}, \mathrm{X}_{5}, \mathrm{X}_{6}, \mathrm{X}_{7}, \mathrm{X}_{8}, \mathrm{X}_{9}, \mathrm{X}_{10}\right)
$$

Table 2. Model specification for determinants of compliance to GAP of cocoa among farmers in Ondo State

\begin{tabular}{|c|c|}
\hline Model & Definition \\
\hline$\overline{X_{1}}$ & Age in years \\
\hline $\mathrm{X}_{2}$ & $\begin{array}{l}\text { Level of education (at least primary } \\
\text { education }=1 \text { otherwise }=0 \text { ) }\end{array}$ \\
\hline$X_{3}$ & $\begin{array}{l}\text { Household size (Number in the } \\
\text { household) }\end{array}$ \\
\hline $\mathrm{X}_{4}$ & Knowledge scores \\
\hline $\mathrm{X}_{5}$ & Challenges scores \\
\hline$X_{6}$ & Economic benefits score \\
\hline $\mathrm{X}_{7}$ & Environmental benefit score \\
\hline $\mathrm{X}_{8}$ & Health benefits score \\
\hline $\mathrm{X}_{9}$ & Cocoa farm size $(\mathrm{Ha})$ \\
\hline $\mathrm{X}_{10}$ & Sex $($ male $=1 ;$ otherwise $=0)$ \\
\hline $\mathrm{X}_{11}$ & $\begin{array}{l}\text { Marital status (married }=1 \text {; otherwise } \\
=0 \text { ) }\end{array}$ \\
\hline $\mathrm{X}_{12}$ & Religion $($ Christianity $=1 ;$ Islam $=0)$ \\
\hline $\mathrm{X}_{13}$ & $\begin{array}{l}\text { Ethnicity } \text { (Yoruba }=1 \text {; Otherwise } \\
=0 \text { ) }\end{array}$ \\
\hline
\end{tabular}

Note: $\mathrm{Y}=$ Compliance (score); The equation in explicit form is: $Y=\beta_{0}+\beta_{1} X_{1}+\beta_{2} X 2+\ldots+$ $\beta 10 \mathrm{X} 13+\varepsilon$. Where $\beta$ represents the slope of the Model and it is defined as unit change (increase or decrease) in the dependent variable when the dependent variable changes by one unit, while $\varepsilon$ is the error term. The hypothesis was tested at $10 \%$ level of significance (Apata et al., 2009; de Haan, n.d.) 


\section{RESULTS AND DISCUSSION}

\section{Knowledge of farmers of GAP of cocoa}

The need to understand farmers' knowledge of GAP of cocoa is important towards validating the place of knowledge as an important precursor of compliance in the presence of other variables. The result in Table 3 reveals that majority of farmers had a good knowledge of the GAP. Of the maximum possible score of 21, the average score was 12.4 and ranged from 5 to 20. Categorization using the mean knowledge score as benchmark shows that a total of $70.0 \%$ had a high knowledge level of GAP. This high knowledge among majority should aid compliance to GAP of cocoa and a good signal for a profitable and sustainable cocoa production. This postulation is supported in previous studies (Okobia et al., 2006; Alazmi et al., 2013). In a similar study, Eghe et al. (2014) had expressed the thought that if producers of cocoa have poor knowledge of GAP which is a pre-requisite for certification, preparedness to adopt and sustain production will be negatively affected.

Table 3. Level of knowledge on GAP

\begin{tabular}{lcccccc}
\hline Level of knowledge & F & $\%$ & Mean & Good deviation & Min. & Max. \\
\hline Low & 45 & 30.0 & 12.41 & 2.37 & 5 & 20 \\
High & 105 & 70.0 & & & & \\
\hline
\end{tabular}

\section{Constraints of farmers to GAP}

The study as shown in Table 4 reveals that majority of cocoa smallholders $(72.7 \%)$ identified and rated high cost of recommended agrochemicals as severe. High cost of labor was also rated as severe among majority (78\%). These two constraints were hence ranked the two most important to farmers' compliance to GAP with weighted mean values of 1.52 and 1.60 , respectively. High cost of appropriate agrochemicals can force farmers to source for and use inappropriate agrochemicals, while high cost of labor can also encourage use of the these agrochemicals as those chemicals often stand as the closest alternatives to the most labor-intensive practice which is weeding.
This finding is corroborated by Mokwunye et al. (2012) where it was revealed that factors such as financial constraints, poor techniques and inappropriate equipment are the reasons farmers do not readily adopt use of recommended agrochemicals and sustainable agricultural practices. Conflict with loggers was rated a severe constraint also by more than twothird $(69.3 \%)$, with $63.3 \%$ giving the same rating to fluctuating prices of cocoa in the international market. Conflict with loggers being rated high $\left(3^{\text {rd }}\right)$ simply shows that cocoa production is faced with environmental constraints which often force farmers to take to environmentally and socially non-beneficial measures.

Table 4. Constraints of farmers to good practices

\begin{tabular}{lrrrrr}
\hline \multicolumn{1}{c}{ Constraints } & Severe & Mild & No constraint & Mean & Rank \\
\hline Access to loans to purchase inputs & 36.7 & 18.7 & 44.7 & 0.92 & 7 \\
High cost of improved cocoa seedling & 44.0 & 9.3 & 46.7 & 0.97 & 6 \\
High cost of recommended agrochemicals & 72.7 & 6.7 & 20.7 & 1.52 & 2 \\
Availability of fake herbicides & 26.0 & 16.7 & 57.3 & 0.69 & 8 \\
Poor knowledge use of recommended agro- & 12.0 & 11.3 & 76.7 & 0.35 & 11 \\
chemicals & & & & & \\
Climate change & 42.7 & 14.0 & 43.3 & 0.99 & 5 \\
High cost of labor & 78.0 & 4.0 & 18.0 & 1.60 & 1 \\
Inadequate information on good practices & 16.0 & 7.3 & 76.7 & 0.39 & 10 \\
Poor record keeping & 9.3 & 16.0 & 74.7 & 0.35 & 11 \\
Inadequate training & 21.3 & 18.7 & 60.0 & 0.61 & 9 \\
Conflict with loggers & 69.3 & 8.0 & 22.7 & 1.47 & 3 \\
Fluctuating prices of cocoa & 63.3 & 4.7 & 32.0 & 1.31 & 4 \\
\hline
\end{tabular}


Climate change, ranked as the $5^{\text {th }}$ constraint with $42.7 \%$ of farmers rating it as severe. This often implies inconsistency in the production pattern due to unpredictable climatic variables and can also affect timeliness of ancillary activities. High cost of seedlings was rated severe by $44 \%$ of respondents and as the $6^{\text {th }}$ most severe constraint. This suggests that farmers would resort to seedlings that are not of hybrid/improved sources which will heighten their vulnerability to disease and pest attacks. This thought concurs with Ogunleye and Oladeji (2007) which revealed farmers' lack of capital as responsible for inability to purchase improved seeds. The result also aligns with that of Rodriguez-Baide (2005) which listed major barriers in adoption of GAP to include economics barriers, education and information barriers, knowledge of application of technology and other social constraints.

\section{Perceived benefits of farmers on GAP}

The result in Table 5 shows that along the perceived economic benefits of GAP, $55.3 \%$ of farmers rated high yield as high. This suggests that farmers, who used appropriate spacing, weed the farm at the recommended time and applied recommended agrochemicals record high yield of cocoa compared to others who deviated from such standard. This result is similar to that of Hoffmann et al. (2020) which attributed increased cocoa yield to acquisition of disseminated GAP skills among smallholder farmers. The study further reveals that $65.3 \%$ rated increased acceptance of cocoa beans with buyers high. In summary, high acceptability, high market value and guaranteed market for cocoa beans were the most rated benefits by farmers.

The results on environmental benefit of GAP reveals that utilization of organic matter, soil nutrient retention and good oxygen level for soil replenishment were the most rated benefits. The result also shows that on the average, the environmental benefit was rated moderate by cocoa farmers. Arsyad et al. (2020) also argues that modern agriculture practices have tended to ignore ecological principles thus contributing to unstable sustainable agro-ecosystems. In the same vein, health benefit perceived most by farmers were reduced respiratory problems in humans $($ mean $=2.25)$, reduced frequency of disease attack (mean $=2.24)$ and strong and agile body (mean $=2.21)$. These benefits were rated moderated by $58.7 \%, 61.3 \%$ and $51.3 \%$, respectively by farmers. While this may suggest that farmers wear protective clothes while handling agrochemicals, it is also a possible indication of good knowledge of GAP demonstrated by cocoa farmers as reported in Table 2. Asare and David (2011) also linked adherence to GAP with good health of farmers and consumers.

Table 5. Benefits of good agricultural practices

\begin{tabular}{lcccccc}
\multicolumn{1}{c}{ Benefits } & High & Moderate & Low & Mean & Rank & Mean of means \\
\hline Perceived economic benefit & & & & & & \\
\hline High product acceptability & 65.3 & 32.0 & 2.7 & 2.63 & 1 & \\
High market value & 58.7 & 40.0 & 1.3 & 2.57 & 2 & \multirow{2}{*}{ Guaranteed market } \\
Increased yield of cocoa & 60.0 & 37.3 & 2.7 & 2.57 & 2 & \\
High overall productivity & 55.3 & 42.0 & 2.7 & 2.53 & 4 & \\
\hline Perceived environmental benefit & 54.7 & 42.7 & 2.7 & 2.52 & 5 & \\
\hline Utilization of organic matter & 25.3 & 58.0 & 16.7 & 2.09 & 1 & \\
Soil nutrient retention & 24.0 & 59.3 & 16.7 & 2.07 & 2 & \\
Soil cover retention & 28.0 & 48.7 & 23.3 & 2.05 & 3 & 2.04 \\
Source of oxygen replenishment & 27.3 & 50.7 & 22.0 & 2.05 & 3 & \\
Minimal soil erosion & 24.0 & 46.0 & 30.0 & 1.94 & 5 & \\
Perceived health benefits & & & & & & \\
\hline Prevention of respiratory issues & 8.0 & 58.7 & 33.3 & 2.25 & 1 & \\
Reduced frequency of disease & 31.3 & 61.3 & 7.3 & 2.24 & 2 & \\
attack & & & & & & \\
Strong and healthy body & 34.7 & 51.3 & 14.0 & 2.21 & 3 & 2.21 \\
Reduced exposure to chemicals & 39.3 & 40.0 & 20.7 & 2.19 & 4 & \\
Prevention from cancer & 36.7 & 41.3 & 22.0 & 2.15 & 5 & \\
\hline
\end{tabular}


It is also noteworthy that the most rated of the three benefit domains was economic which averagely was rated high $(2.56 \approx 3)$, while environmental (2.04) and health benefits (2.21) were both rated average. The perception of farmers which is indicative that they have experienced the relative advantages of GAP agrees with the Poisot (2014)'s definition. Poisot et al. (2004) had itemized availability of safe and healthy food, economic and environmental sustainability of production across the on-farm production and post-production processes as benefits of GAP.

\section{Compliance to GAP}

Results in Table 6 shows that $54 \%$ of farmers complied with GAP while $46 \%$ were not compliant. Specifically, the study (Table 7) reveals that although farmers achieved a high level of compliance with a number of indicators of GAP, a closer look at the few items to which majority did not comply implicates such of relatively bigger economic, health and environmental implications. For example, only a small proportion were compliant with appropriateness of fertilizer application (2.3\%), use of herbicides (36.7\%) and use of recommended fumigants (3.3\%). Use of recommended insecticides (28.7\%), application of fertilizer $(6.0 \%)$ and fungicides $(2.7 \%)$ were also only complied with by small fractions of cocoa farmers. This may be the explanation for the low acceptability of cocoa beans of Nigeria origin in the international market as posited by Gumm (2010) and Ogundele (2018).

Table 6. Level of compliance to good agricultural practices among cocoa farmers

\begin{tabular}{lcccccc}
\hline \multicolumn{1}{c}{ Level of compliance } & F & $\%$ & Mean & Good deviation & Min. & Max. \\
\hline Not compliant & 69 & 46 & 44.50 & 8.649 & 0.00 & 20.00 \\
Complaint & 81 & 54 & & & & \\
\hline
\end{tabular}

Table 7. Compliance to GAP among cocoa farmers

\begin{tabular}{lc}
\hline \multicolumn{1}{c}{ Recommended practices } & Percentage (\%) \\
\hline Good planting spacing & 65.3 \\
Use of plantain as a shade plant & 93.3 \\
Appropriate tillage depth & 78.7 \\
Appropriate weeding frequency & 30.0 \\
Replacement of dead or disease seedlings & 82.0 \\
Cutting down trees and burning them before planting & 78.0 \\
Getting seedlings from the nursery & 59.3 \\
Appropriate fertilizer use (twice a year) & 21.3 \\
Pruning of young cocoa plants & 79.3 \\
Record keeping of stocks and parent material & 30.0 \\
Use of Glyphosate as herbicide & 36.7 \\
Recommended fumigant (e.g Photoxin) & 3.3 \\
Application of fertilizer & 6.0 \\
Recommended insecticide (e.g Acephate) & 28.7 \\
Use of recommended fungicides & 2.7 \\
Direct sowing of seeds & 73.3 \\
Appropriate fermentation period 6-10 days & 76.0 \\
Appropriate drying period of 5-10 days & 70.7 \\
Sorting cocoa beans & 92.0 \\
Appropriate duration of drying (more than 2 weeks) & 2.0 \\
Grading of cocoa beans & 78.0 \\
\hline
\end{tabular}

The estimation of the regression model as presented in Table 8 reveals that five of the thirteen independent variables regressed on the compliance of farmers to GAP gave a coefficient of determination $\left(\mathrm{R}^{2}\right)$ of 0.46 , which shows that the variation in the compliance level of cocoa farmers to GAP is explained to about $46 \%$ by the identified variables. Keeping other 
factors constant, a unit increase in knowledge score increases the compliance level by 1.95 . This shows that farmers with high level of knowledge on GAP of cocoa complied with the set standards, thus a high level of compliance to GAP of cocoa. This agrees with Awoyemi and Aderinoye-Abdulwahab (2019) who found that level of cocoa management practices improves with increase in farmers' knowledge. It also agrees with earlier postulation by Okobia et al. (2006) and Alazmi et al. (2013) that knowledge is an essential requirement to appropriate practice of any innovation. The result is also consistent with Lee (2007) on importance of information and skills.

Also, farmers perceived economic $(\beta=0.93)$ and health $(\beta=0.88)$ benefits were implicated as significant determinants of compliance to GAP of cocoa. This implies that farmers who obtained more premium price from sales of quality and healthy cocoa beans are better motivated to adopt the GAP as it often helps to recover costs accrued during pre-planting through post-harvest stages. This is in consonance with the findings of Adefemi (2019) which asserts that farmers who comply with good management practices have so much to gain after all as they are able to recover costs incurred in their farm operations after sales of their beans. Parikhani et al. (2015) also identified economic factors as important to compliance to
GAP. Other authors have also linked GAP to improved income and hence livelihood of smallholders (Jumiyati et al., 2018; Arsyad et al., 2020). The study however disagrees with Olutegbe and Samuel (2020) on the importance of considering relative economic advantage in making choices. The socioeconomic variable, family size, contributing significantly to use of GAP in the regression model is a validation of earlier assertions that the family remains an important labor source for cocoa farming activities in Nigeria (Obike et al., 2016; Akinnagbe et al., 2018).

Generally, the finding disagrees with Santos-Ordóñez (2011) which showed that availability of family labor and additional income influenced Ecuadorian farmers' adoption of cocoa rehabilitation techniques. It also defies several postulations that age and formal education (Clay et al., 1998) and farm size (Ayanwuyi et al., 2010) are important predictors of adoption of innovative agricultural practices and associated variables. It however concurs with the findings of Olutegbe and Fadairo (2016) which established no significant relationship between farmers' marital status, age, formal education with farmers' responsiveness to appropriate climate change adaptation. The result also agrees with Apata et al. (2009) on sex and Gibbon (2009) and Ayanwuyi et al. (2010) on non-importance of formal education to adoption decision.

Table 8. Isolating determinants of small-holder farmers' compliance to GAP of cocoa

\begin{tabular}{lcccc}
\hline \multicolumn{1}{c}{ Model } & \multicolumn{2}{c}{ Unstandardized } & $\mathrm{t}$ & Sig. \\
\hline & $\mathrm{B}$ & Std. Error & & \\
Constant & 39.508 & 13.937 & 2.835 & 0.005 \\
Age & -0.180 & 0.570 & -0.322 & 0.748 \\
Level of education (formal =1, otherwise $=0$ ) & -2.510 & 0.701 & -0.358 & 0.721 \\
Household size & -0.602 & 0.298 & $-2.016^{* *}$ & 0.046 \\
Knowledge scores & 1.949 & 0.263 & $7.435^{* * *}$ & 0.000 \\
Constraints scores & -.264 & 0.138 & -1.913 & 0.058 \\
Economic benefits & .934 & 0.289 & $3.235^{* * *}$ & 0.002 \\
Environmental benefit & 0.294 & 0.249 & 1.181 & 0.240 \\
Health benefits & 0.876 & 0.237 & $3.701 * * *$ & 0.000 \\
Cocoa farm size & -.365 & 0.341 & -1.070 & 2.870 \\
Sex (male $=1$, otherwise $=0$ ) & -1.361 & 2.696 & -0.505 & 0.615 \\
Marital status (married $=1$, otherwise $=0$ ) & .252 & 2.951 & 0.085 & 0.932 \\
Religion $($ Christian $=1$, otherwise $=0$ ) & -2.525 & 1.292 & $1.954^{*}$ & 0.053 \\
Ethnicity (Yoruba $=1$, otherwise $=0$ ) & -8.921 & 7.816 & -1.141 & 0.256 \\
\hline Note: $\mathrm{R}^{2}=0.457 ; \mathrm{R}=0.676 ; \mathrm{F}=7.338 ; * * *=$ significant at $1 \% ; * *=$ significant at $5 \% ; *=$ significant at $10 \%$
\end{tabular}




\section{CONCLUSIONS}

The study concludes that perceived economic and health benefits were the most important predictors of compliance to GAP. The knowledge of GAP, also key to compliance, validates assertions linking it to compliance. The result disagrees with earlier positions on importance of some socioeconomic variables to adoption of recommended practices, but underscores the mediatory roles played by family size, further confirming that the family remains a major labor source for cocoa farming in Ondo State. There is the need to educate cocoa farmers on GAP in order to sharpen their skills on profitable and sustainable management practices in cocoa enterprise.

\section{ACKNOWLEDGMENTS}

The authors acknowledge the contributions of all academic staffers in the Department of Agricultural Extension and Rural Development, University of Ibadan, for their invaluable contributions which enriched this study. The cooperative disposition of the leaders of Cocoa Farmers Association and other contact persons in selected communities/LGAs of Ondo State, where this study was carried out, is also much acknowledged.

\section{REFERENCES}

Adefemi, O. J. (2019). Profitability and efficiency analysis of cocoa marketing in Ondo State , Nigeria. Journal of Business and African Economy, 5(1), 8-18. Retrieved from https://iiardpub.org/get/JBAE/VOL.\%205\%2 0NO.\%201\%202019/PROFITABILITY\%20 AND\%20EFFICIENCY.pdf

Adegeye, A. J. (1996). Production and marketing of cocoa in Nigeria, problem and solution. Proceedings of National Seminal on Revolutionalising Nigeria's Cocoa Industry, Ibadan, Nigeria.

Afolayan, O. S. (2017). Problems and prospects of cocoa production in Nigeria economy: A review. International Journal of Social Sciences, 11(2), 32-43. Retrieved from http:// socialscienceuniuyo.com/wp-content/uploads/ 2017/09/Article-3-Samuel-A.-O..pdf

Afolayan, O. S. (2020). Cocoa production pattern in Nigeria : The missing link in regional agro- economic development. Analele Universitătii Din Oradea, Seria Geografie, 30(1), 88-96. https://doi.org/10.30892/auog.301110-815

Afolayan, O. S., \& Ajibade, L. T. (2012). Temporal variation in perennial cash crops production in Ondo State, Nigeria. Asian Journal of Natural and Applied Sciences, 1(3), 72-78. Retrieved from http://www.ajsc.leenaluna.co.jp/AJSCPDFs/Vol.1(3)/AJSC2012(1. 3-07).pdf

Aikpokpodion, P. E. (2010). Nutrients dynamics in cocoa soils, leaf and beans in Ondo State, Nigeria. Journal of Agricultural Sciences, 1(1), 1-9. https://doi.org/10.1080/09766898. 2010.11884647

Ajayi, I., Afolabi, M., Ogunbodede, E., \& Sunday, A. (2010). Modeling rainfall as a constraining factor for Cocoa yield in Ondo State. American Journal of Scientific and Industrial Research, l(2), 127-134. https://doi.org/10.5251/ajsir. 2010.1.2.127.134

Akinnagbe, O. M., Adeniran, T. P., \& Adeniran, A. A. (2018). Intra-household roles in cocoa production in Ondo State, Nigeria. Journal of Agricultural Extension, 22(3), 77-86. https:// doi.org/10.4314/jae.v22i3.8

Alazmi, S. F., Alkhabbaz, A., Almutawa, H. A., Ismaiel, A. E., Makboul, G., \& El-Shazly, M. K. (2013). Practicing breast self-examination among women attending primary health care in Kuwait. Alexandria Journal of Medicine, 49(3), 281-286. https://doi.org/10.1016/j.ajme .2012 .08 .009

Apata, T. G., Samuel, K. D., \& Adeola, A. O. (2009). Analysis of climate change perception and adaptation among food crop farmers in South Western Nigeria. International Association of Agricultural Economists' 2009 Conference, 15. Retrieved from https://www. researchgate.net/publication/254463276_Anal ysis_of_Climate_Change_Perception_and_Ad aptation_among_Arable_Food_Crop_Farmers _in_South_Western_Nigeria

Arsyad, M., Sabang, Y., Agus, N., Bulkis, S., \& Kawamura, Y. (2020). Intercropping farming system and farmers income. Agrivita, 42 (2), 360-366. https://doi.org/10.17503/agrivita .v42i2.2724

Asare, R., \& David, S. (2011). Good agricultural 
practices for sustainable cocoa production : a guide for farmer training. Manual No. 1: Planting, replanting and tree diversification in cocoa systems. Accra, Ghana: Sustainable tree crops programme. International Institute of Tropical Agriculture. Retrieved from http://biblio.iita.org/documents/U11ManAsar ePlantingNothomNodev.pdf-66a7d381ce34c6 f69507cc1a51506a2f.pdf

Awe. (2013). Nigeria exports cocoa to import chocolates is sad. Punch Newspaper, January 30, 2013.

Awoyemi, A. O., \& Aderinoye-Abdulwahab, S. A. (2019). Assessment of the use of cocoa production management practices among cocoa farmers in Ekiti State, Nigeria. AgroScience, 18(2), 37-41. https://doi.org/10.4314/ as.v18i2.7

Ayanwuyi, Kuponiyi, E., Ogunlade, F. A., \& Oyetoro, O. J. (2010). Farmers perception of impact of climate changes on food crop production in Ogbomoso Agricultural Zone of Oyo State, Nigeria. Global Journal of Human Social Science, 10(7), 33-39. Retrieved from https://globaljournals.org/ GJHSS_Volume10/7-Farmers-Perception-ofImpact-of-Climate.pdf

Banzon, A. T., Mojica, L. E., \& Cielo, A. A. (2013). Adoption of good agricultural practices (GAP) in the Philippines: challenges, issues, and policy imperatives. Policy Brief Series - Southeast Asian Regional Center for Graduate Study and Research in Agriculture (SEARCA), 2013(1), 2. Retrieved from https:// www.researchgate.net/publication/331220391 _Adoption_of_Good_Agricultural_Practices_ GAP_in_the_Philippines_Challenges_Issues and_Policy_Imperatives_SEARCA_Policy_B rief_Series

Beg, M. S., Ahmad, S., Jan, K., \& Bashir, K. (2017). Status, supply chain and processing of cocoa - A review. Trends in Food Science and Technology, 66, 108-116. https://doi.org/ 10.1016/j.tifs.2017.06.007

Cadoni, P. (2013). Analysis of Incentives and Disincentives for Cocoa in Nigeria. Technical notes series, MAFAP. Rome: FAO. Retrieved from http://www.fao.org/3/a-at586e.pdf

Clay, D., Reardon, T., \& Kangasniemi, J. (1998).
Sustainable intensification in the highland tropics: Rwandan farmers' investments in land conservation and soil fertility. Economic Development and Cultural Change, 46(2), 351-377. https://doi.org/10.1086/452342

de Haan, M. (n.d.). ECON4150 - Introductory Econometrics Lecture 5: OLS with One Regressor: Hypothesis Tests. Retrieved from https://www.uio.no/studier/emner/sv/oekono mi/ECON4150/v17/lecture7_ols_multiple_re gressors_hypothesis_tests.pdf

Eghe, A. A., Taiwo, O., Busayo, S. F., \& Olumide, J. O. (2014). Perception of cocoa farmers to voluntary standard certification : An implication on Cocoa Transformation in Nigeria. IOSR Journal of Agriculture and Veterinary Science, 7(6), 17-20. Retrieved from http://www.iosrjournals.org/iosr-javs/pa pers/vol7-issue6/Version-1/D07611720.pdf

Gibbon, D. (2009). Climate change and agriculture in Africa: Impact Assessment and Adaptation Strategies. Edited by Dinar, A., Hassan, R., Mendelsohn, R., \& Benhin, J. London: Earthscan/Centre for Environmental Economics and Policy in Africa (CEEPA) (2008), pp. 189 (Book Review). Experimental Agriculture, 45(2), 235-236. https://doi.org/ $10.1017 / \mathrm{s} 0014479708007278$

Gumm, D. (2010). Nigeria cocoa faces export ban - Vanguard News. Vanguard News. https://www.vanguardngr.com/2010/08/nigeri a-cocoa-faces-export-ban/

Hoffmann, M. P., Cock, J., Samson, M., Janetski, N., Janetski, K., Rötter, R. P., Fisher, M., \& Oberthür, T. (2020). Fertilizer management in smallholder cocoa farms of Indonesia under variable climate and market prices. Agricultural Systems, 178, 102759. https:// doi.org/10.1016/j.agsy.2019.102759

Ibiremo, O. S., Daniel, M. A., Iremiren, G. O., \& Fagbola, O. (2011). Soil fertility evaluation for cocoa production in Southeastern Adamawa State, Nigeria. World Journal of Agricultural Sciences, 7(2), 218-223. Retrieved from https://library.wur.nl/isric/fulltext/isricu_i300 70_001.pdf

Jumiyati, S., Arsyad, M., Rajindra, Pulubuhu, D. A. T., \& Hadid, A. (2018). Cocoa based agroforestry: An economic perspective in 
resource scarcity conflict era. IOP Conference Series: Earth and Environmental Science, 157(1), 012009. https://doi.org/10.1088/1755$1315 / 157 / 1 / 012009$

Lee, B. L. (2007). Information technology and decision support system for on-farm applications to cope effectively with agrometeorological risks and uncertainties. Managing Weather and Climate Risks in Agriculture, 191-207. https://doi.org/10.1007/ 978-3-540-72746-0_12

Mokwunye, I. U., Babalola, F. D., Ndagi, I., Idrisu, M., Mokwunye, F. C., \& Asogwa, E. U. (2012). Farmers' compliance with the use of approved cocoa pesticides in cocoa producing states of Nigeria. Journal of Agriculture and Social Research (JASR), 12(2), 44-60. Retrieved from https://www.ajol.info/index. php/jasr/article/view/112522

Morgan-Davies, C., Wilson, R., \& Waterhouse, T. (2017). Impacts of farmers' management styles on income and labour under alternative extensive land use scenarios. Agricultural Systems, 155, 168-178. https://doi.org/ 10.1016/j.agsy.2017.04.011

National Bureau of Statistic - Nigeria. (2013a). Report on national survey of exportable agricultural commodities in Nigeria. Retrieved from http://nigeria.countrystat.org/ documents/detail/en/c/454826/

National Bureau of Statistic - Nigeria. (2013b). Nigeria - National survey of agricultural export commodities 2007, Fourth round Overview. Retrieved from https://nigerianstat. gov.ng/nada/index.php/catalog/4

Obike, K. C., Idu, M. A., \& Aigbokie, S. O. (2016). Labour productivity and resource use efficiency in cocoa farming in Abia State, Nigeria. Agro-Science, 15(3), 7-12. https:// doi.org/10.4314/as.v15i3.2

Ogundele, K. (2018). Why Nigeria's cocoa can't compete in global market $-N E P C$. Punch Newspapers. Retrieved from https://punchng. com/why-nigerias-cocoa-cant-compete-in-glo bal-market-nepc/

Ogunleye, K. Y., \& Oladeji, J. O. (2007). Choice of cocoa market channels among cocoa farmers in ILA local government area of Osun State, Nigeria. Middle-East Journal of
Scientific Research, 2(1), 14-20. Retrieved from https://www.researchgate.net/publicatio n/237699628_Choice_of_Cocoa_Market_Cha nnels_among_Cocoa_Farmers_in_ILA_Local _Government_Area_of_Osun_State_Nigeria

Okobia, M. N., Bunker, C. H., Okonofua, F. E., \& Osime, U. (2006). Knowledge, attitude and practice of Nigerian women towards breast cancer: A cross-sectional study. World Journal of Surgical Oncology, 4, 11. https://doi.org/ 10.1186/1477-7819-4-11

Okojie, J. (2020). Nigeria's cocoa midcrop export to shrink as coronavirus hits global demand Businessday NG. Retrieved from https:// businessday.ng/agriculture/article/nigerias-co coa-midcrop-export-to-shrink-as-coronavirushits-global-demand/

Olutegbe, N. S, \& Fadairo, O. S. (2016). Correlates and determinants of climate change adaptation strategies of food crop farmers in Oke-Ogun area of South-western Nigeria. Journal of Agricultural Extension and Rural Development, 8(7), 122-129. https://doi.org/ 10.5897/JAERD2014.0651

Olutegbe, N. S., \& Samuel, A. A. (2020). Determinants of acceptability and use of indigenous cosmetics among patrons in Ibadan Metropolis, Nigeria: Implication for rural livelihood. International Journal of Social Sciences Perspectives, 7(2), 89-98. https:// doi.org/10.33094/7.2017.2020.72.89.98

Owoeye, R. S., \& Sekumade, A. B. (2016). Effect of climate change on cocoa production in Ondo State, Nigeria. Journal of Social Science Research, 10(2), 2014-2025. https://doi.org/ 10.24297/jssr.v10i2.4730

Parikhani, M. P., Borkhani, F. R., Fami, H. S., Motiee, N., \& Hosseinpoor, A. (2015). Major barriers to application of Good Agricultural Practices (GAPs) technologies in sustainability of livestock units. International Journal of Agricultural Management and Development (IJAMAD), 5(3), 169-178. Retrieved from https://econpapers.repec.org/ article/agsijamad/262508.htm

Paschall, M., \& Seville, D. (2012). Certified Cocoa: scaling up farmer participation in West Africa. London, UK: International Institute for Environment and Development/ 
Sustainable Food Lab 2012. Retrieved from https://pubs.iied.org/pdfs/16034IIED.pdf

Poisot, A. S., Speedy, A., \& Kueneman, E. (2004). Good agricultural practices - a working concept background paper for the FAO internal workshop on good agricultural practices. In FAO GAP Working Paper Series (Issue October). Retrieved from http://www. fao.org/tempref/docrep/fao/010/ag856e/ag856 e00.pdf

Rodriguez-Baide, J. M. (2005). Barriers to adoption of sustainable agriculture practices in the south: change agent's perspectives [Thesis]. Salem, Oregon, USA: Auburn University. Retrieved from https://etd.auburn. edu/xmlui/handle/10415/878

Santos-Ordóñez, A. P. (2011). Determinants factors of bio-fertilizer and technical adoption to rehabilitate cocoa farms variety "national" in Guayas and El Oro provinces-Ecuador [Thesis]. Belgium: Ghent University. Retrieved from https://lib.ugent.be/fulltxt/RU G01/001/789/921/RUG01-001789921_2012_ 0001_AC.pdf

Zhen, L., \& Routray, J. K. (2003). Operational indicators for measuring agricultural sustainability in developing countries. Environmental Management, 32(1), 34-46. https://doi.org/10.1007/s00267-003-2881-1 